\title{
In Vitro Corrosion Characteristics of Commercially Available Orthodontic Wires
}

\author{
Yasuyuki YONEKURA ${ }^{1}$, Kazuhiko ENDO ${ }^{2}$, Masahiro IIJIMA ${ }^{1}$, Hiroki OHNO ${ }^{2}$ and Itaru MIZOGUCHI ${ }^{1}$ \\ ${ }^{1}$ Department of Orthodontics \\ ${ }^{2}$ Department of Dental Materials Science School of Dentistry, Health Sciences University of Hokkaido 1757, Ishikari-tobetsu, \\ Hokkaido 061-0293, Japan \\ Corresponding author, E-mail:iijima@hoku-iryo-u.ac.jp
}

Received January 16, 2004/Accepted March 19, 2004

\begin{abstract}
The corrosion characteristics of orthodontic alloy wires were investigated both in as-received and grinded conditions in $0.9 \%$ $\mathrm{NaCl}$ solution by atomic absorption spectrophotometry and potentiodynamic polarization measurements. The amount of each metal ion released from most alloys was larger for the grinded wires than for the as-received wires $(p<0.01)$. The fact that the beta-Ti alloy wire (Ti-Mo-Zr) does not contain allergenic metals such as $\mathrm{Ni}$, Co, and $\mathrm{Cr}$, and the finding that resistance to both general and localized corrosion is the highest among the six wires investigated suggest that this wire is the most biocompatible orthodontic wire. Since a small amount of $\mathrm{Ni}, \mathrm{Cr}$ or $\mathrm{Co}$ ions were released from $\mathrm{Ni}-\mathrm{Ti}$, Co-Cr and stainless steel wires, special attention should be paid during their clinical use for patients with allergic tendencies.
\end{abstract}

Key words: Corrosion, Orthodontic wire, Hypersensitivity reaction

\section{INTRODUCTION}

Currently, orthodontists principally use wires of four major base metal alloy types: stainless steel, Co-Cr$\mathrm{Ni}$ alloy, Ni-Ti alloy and beta-Ti alloy ${ }^{1,2}$. Except for beta-Ti alloy, these orthodontic wire alloys contain $\mathrm{Ni}$, which produces more allergic reactions than any other metal ${ }^{3,4)}$. Incidences of $\mathrm{Ni}$ hypersensitivity reaction were observed during orthodontic treatment using Ni-containing wires ${ }^{5,6)}$. Bass et al. ${ }^{3)}$ also suggested a risk of sensitizing patients to $\mathrm{Ni}$ with longterm exposure to $\mathrm{Ni}$-containing appliances in clinical use. In addition to $\mathrm{Ni}$ ions, other metal ions such as $\mathrm{Cr}$ and $\mathrm{Co}$ ions are also a common cause of allergic contact dermatitis ${ }^{7)}$. Since these adverse biological responses are triggered by a small amount of released metal ions, the amount of metal ions from the typical orthodontic wires should be quantitatively evaluated.

Our previous study demonstrated that the structure of the surface oxide film affected the corrosion resistance of the $\mathrm{Ni}-\mathrm{Ti}$ alloy wire in $0.9 \% \mathrm{NaCl}$ and $1 \%$ lactic acid solutions ${ }^{8)}$. The oxide film on the asreceived wire might be peeled off by tying ligature wire, making contact with the edge of the bracket slot and cutting the distal end in the clinical condition, which may influence the dissolution of metal ions. The susceptibility of the wires to localized corrosion, such as crevice corrosion and dissimilar metal corrosion, is also an important factor, which affects the dissolution of metal ions since an incidence of the localized corrosion usually results in a drastic increase in the amount of metal ions. Although there are several recent studies that have analyzed released metal ions ${ }^{9-11)}$, most of them only focused on released $\mathrm{Ni}$ and $\mathrm{Cr}$ ions, and they did not discuss the susceptibility of the wires to localized corrosion and the effects of oxide film preformed on the as-received wire surface.

The purpose of this study was to assess the corrosion characteristics of commercially available major orthodontic wires. The amount of metal ions released from the wires freely immersed in $0.9 \% \mathrm{NaCl}$ solution was determined by atomic absorption spectrophotometry. The stability of passivity and the susceptibility to localized corrosion was examined by potentiodynamic polarization measurements. The effects of grinding on both general and localized corrosion resistance of the wires were also investigated.

\section{MATERIALS AND METHODS}

\section{Materials}

Six orthodontic wires were employed in this study. The nominal compositions (mass \%) for these wires are shown in Table 1. Ni-Ti was a near-equiatomic $\mathrm{Ni}-\mathrm{Ti}$ alloy wire (Sentalloy yellow, Tomy International, Tokyo, Japan). Ti-Mo-Zr was a beta-Ti alloy wire containing about $11 \% \mathrm{Mo}, 6 \% \mathrm{Zr}$ and $4 \% \mathrm{Sn}$ (TMA wire, Ormco, CA, U.S.A.). Co-Cr was a Co$\mathrm{Cr}-\mathrm{Ni}$ alloy wire containing $15 \% \mathrm{Ni}$ and $16 \% \mathrm{Fe}$ along with $\mathrm{Co}$ and $\mathrm{Cr}$ (Elgiloy blue, Rocky Mountain Orthodontics, CO, U.S.A.). The SS1 (Permachrome Standard, 3M Unitek, CA, U.S.A.) and SS2 (Remanium, Dentaurum, Pforzheim, Germany) were austenitic stainless steel containing about $8-9 \% \mathrm{Ni}$. The SS3 was a high-nitrogen austenite stainless steel with less than $0.1 \% \mathrm{Ni}$ (Noninium, Dentaurum, Pforzheim, Germany). The cross section dimensions of these wires were $0.016 \times 0.022$ inch (rectangular 
Table 1 Composition of the wires used in this study (wt.\%)

\begin{tabular}{|c|c|c|c|c|c|c|c|c|c|c|c|c|c|c|}
\hline Alloys & $\mathrm{Ni}$ & $\mathrm{Ti}$ & $\mathrm{Fe}$ & $\mathrm{Cr}$ & $\mathrm{Mn}$ & $\mathrm{Si}$ & $\mathrm{S}$ & $\mathrm{C}$ & Co & Mo & $\mathrm{Be}$ & $\mathrm{N}$ & $\mathrm{Zr}$ & $\mathrm{Sn}$ \\
\hline $\mathrm{Ni}-\mathrm{Ti}$ & $55.5^{*}$ & $44.1^{*}$ & - & - & - & - & - & - & - & - & - & - & - & - \\
\hline Ti-Mo-Zr & - & Rest & - & - & - & - & - & - & - & $11.3^{\text {ก }}$ & - & - & $6.6^{\Upsilon 1}$ & $4.3^{\Upsilon}$ \\
\hline $\mathrm{Co}-\mathrm{Cr}$ & $15^{\Uparrow}$ & - & $15.8^{\pi}$ & $20^{\pi}$ & $2^{\pi}$ & - & - & $0.15^{\text {ๆ }}$ & $40^{9}$ & $7^{\Uparrow}$ & $0.04^{\pi}$ & - & - & - \\
\hline SS1 & $9.3^{\dagger}$ & - & Rest & $18.3^{\dagger}$ & $1.3^{\dagger}$ & $0.75^{\dagger}$ & $0.04^{\dagger}$ & $0.03^{\dagger}$ & - & - & - & - & - & - \\
\hline SS2 & $8.3^{\dagger}$ & - & Rest & $16.7^{\dagger}$ & $1.1^{\dagger}$ & $1.1^{\dagger}$ & $0.3^{\dagger}$ & $0.1^{\dagger}$ & - & $0.3^{\dagger}$ & - & - & - & - \\
\hline SS3 & $0.1^{\dagger}$ & - & Rest & $17.7^{\dagger}$ & $16.4^{\dagger}$ & $0.9^{\dagger}$ & $0.01^{\dagger}$ & $0.1^{\dagger}$ & - & $2.1^{\dagger}$ & - & $1.0^{\dagger}$ & - & - \\
\hline
\end{tabular}

The values were obtained by ${ }^{*}$ gravimetric analysis or ${ }^{\dagger}$ fluorescence $\mathrm{x}$-ray analysis, or was "provided by the manufacturers.
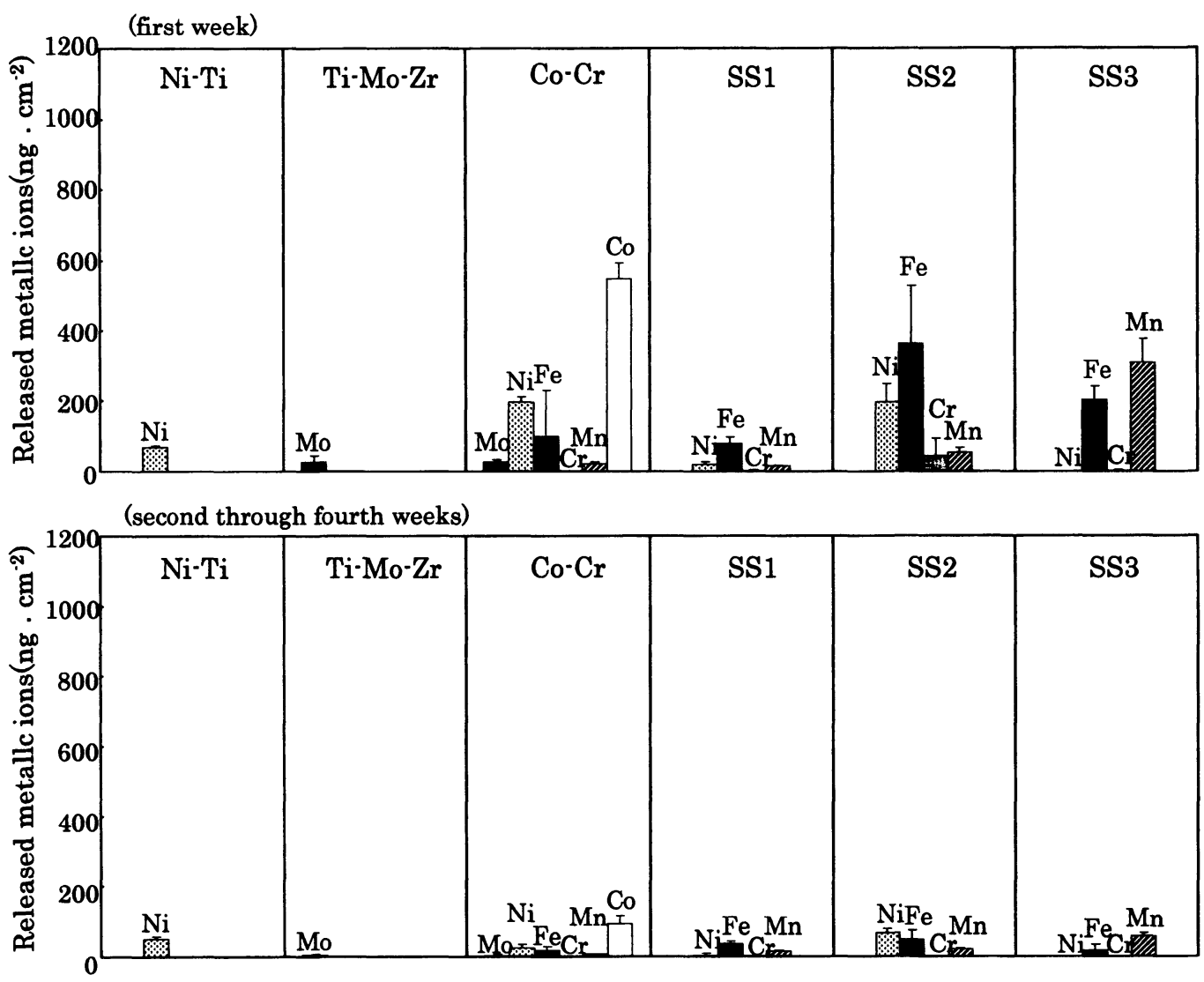

Fig. 1 Amount of released metallic ions from as-received wires after immersion in $0.9 \% \mathrm{NaCl}$ solution.

wire) for Ni-Ti, Ti-Mo-Zr, Co-Cr and SS1, and 0.028 inch (round wire) for SS2 and SS3. These wires were subjected to corrosion tests both in the asreceived condition and after grinding with \#600-grid silicone carbide paper (grinded condition).

\section{Immersion test}

The as-received and grinded wires were totally immersed in $20 \mathrm{ml}$ of $0.9 \% \mathrm{NaCl}$ solution in a polystyrene dish at $37^{\circ} \mathrm{C}^{8)}$. After one week, the specimens were removed from the solution, rinsed with deionized water, and then again immersed in a freshly prepared $0.9 \% \mathrm{NaCl}$ solution. The specimens were finally removed from $0.9 \% \mathrm{NaCl}$ solution after four weeks. To prevent adsorption of dissolved metallic ions, the $1 \mathrm{~mol} \mathrm{HNO}_{3}$ solution was added to the $0.9 \% \mathrm{NaCl}$ solution to achieve a concentration of 0.1 mol before the quantitative analysis. The amount of metallic ions released into the solution was determined using a graphite furnace atomic absorption spectrophotometer (AAS:5100ZL, Perkin Elmer, Norwalk U.S.A.). The means and standard deviation of the amount of metallic ions were calculated $(n=8)$. The results were statistically analyzed by the Student's t-test at a $p=0.01$ level.

\section{Potentiodynamic polarization measurement}

The anodic corrosion behavior of the as-received and 

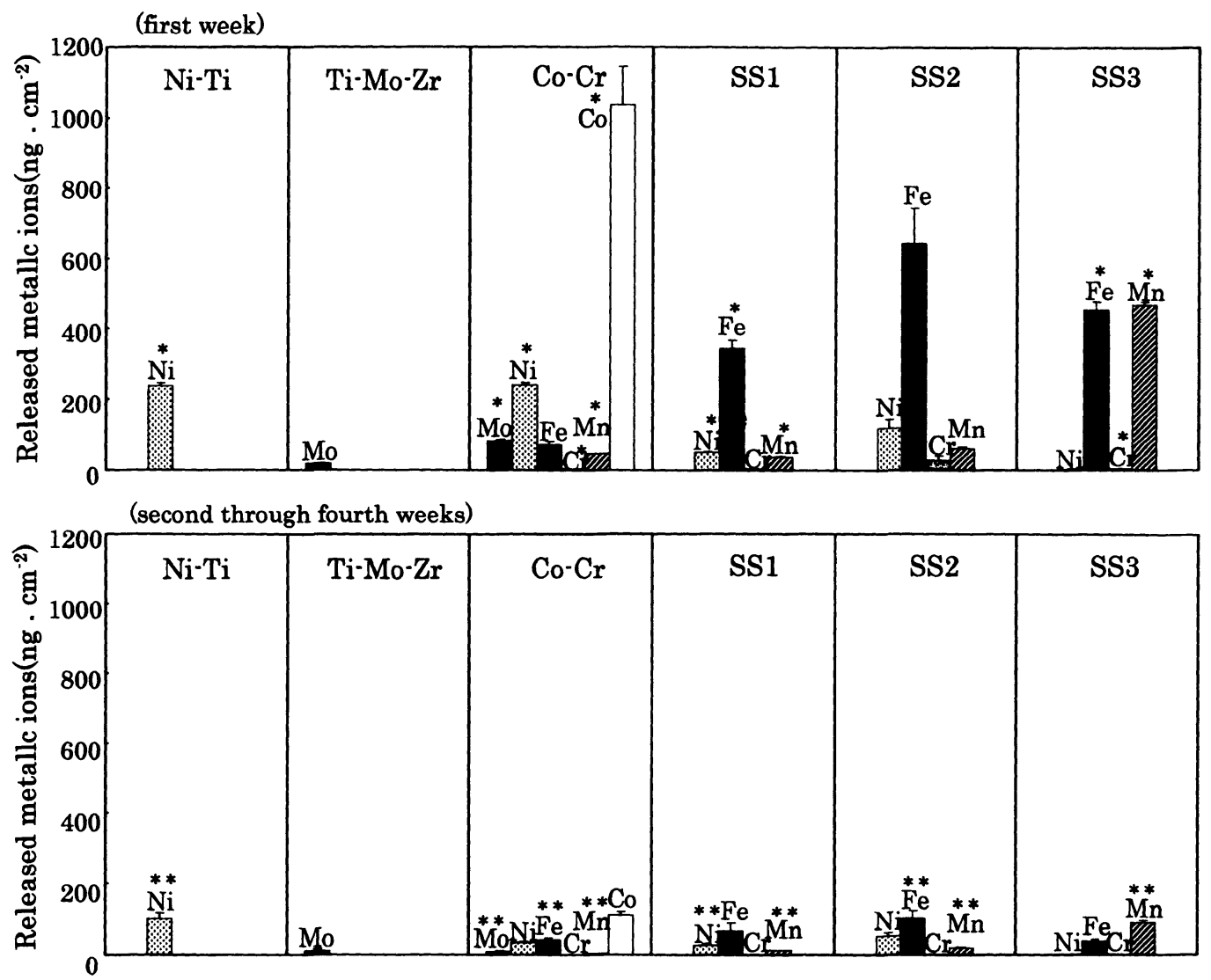

Fig. 2 Amount of released metallic ions from grinded wires after immersion in $0.9 \% \mathrm{NaCl}$ solution. ${ }^{*}$ Mean amount of released metallic ions in the first one week of immersion was significantly different between as-received and grinded wires $(\mathrm{p}<0.01)$. ${ }^{* *}$ Mean amount of released metallic ions in the second through fourth weeks of immersion was significantly different between as-received and grinded wires $(p<0.01)$.

grinded wires was examined by potentiodynamic polarization measurement in $0.9 \% \mathrm{NaCl}$ solution at 37 ${ }^{\circ} \mathrm{C}$. The solution was deaerated by bubbling ultra high purity argon gas for at least $60 \mathrm{~min}$ before introducing the sample to the three electrode cells. Bubbling was continued throughout the measurement. A platinum wire and an $\mathrm{Ag} / \mathrm{AgCl}$ electrode were employed as a counter and a reference electrode, respectively. At $60 \mathrm{~min}$ after specimen immersion, the polarization measurements were carried out using a potentiostat (Model 2090, Toho Giken, Tokyo, Japan) started from the free corrosion potential at a scan rate of $0.17 \mathrm{mV} \cdot \mathrm{s}^{-1}$. The potentiodynamic polarization measurements were repeated three times using different specimens for each sample.

\section{RESULTS}

Immersion test

Fig. 1 shows the amount of metallic ions released from the as-received wires after immersion in $0.9 \%$ $\mathrm{NaCl}$ solution. Small amounts of $\mathrm{Ni}$ and $\mathrm{Mo}$ ions were preferentially released from the $\mathrm{Ni}-\mathrm{Ti}$ and $\mathrm{Ti}$ -
Mo-Zr wires. The amounts of titanium ions released from two Ti alloys wires were below the detection limit $\left(12 \mathrm{ng} / \mathrm{cm}^{2}\right)$. For the $\mathrm{Co}-\mathrm{Cr}$ wire, the amount of released Co ions was the largest $\left(550 \mathrm{ng} / \mathrm{cm}^{2}\right)$ followed by $\mathrm{Ni}, \mathrm{Fe}, \mathrm{Mo}, \mathrm{Mn}$ and $\mathrm{Cr}$ ions. The amount of released metal ions from the stainless steel wires depended largely on its chemical composition. The principal metal ions released from the SS1 and SS2 wires were $\mathrm{Fe}$ and $\mathrm{Ni}$ ions, and those from the SS3 wire were $\mathrm{Mn}$ and $\mathrm{Fe}$ ions. In both as-received and grinded wires, the total amount of metal ions released during the first one week of immersion was larger than that during the subsequent three weeks of immersion as shown in Figs. 1 and 2, indicating that the corrosion rate of the wires decreased with the passage of immersion time in $0.9 \% \mathrm{NaCl}$ solution. The kind of metal ions released from each polished wire and their relative concentration were almost the same as those for the as-received wire. However, the amount of each metal ion released from most alloys was statistically larger for the grinded wires than for the as-received wires $(p<0.01)$. 


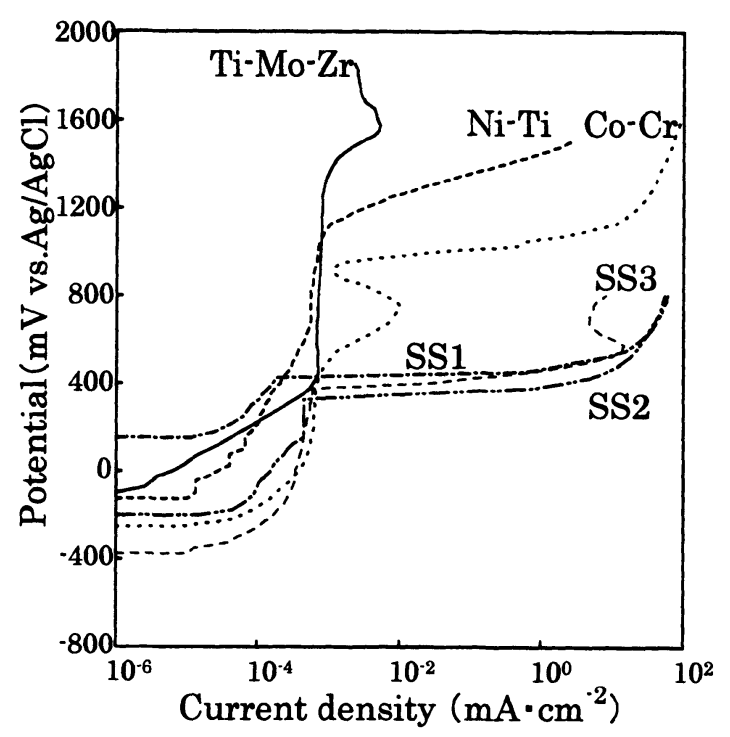

Fig. 3 Potential/current density curves of asreceived wires in $0.9 \% \mathrm{NaCl}$ solution.

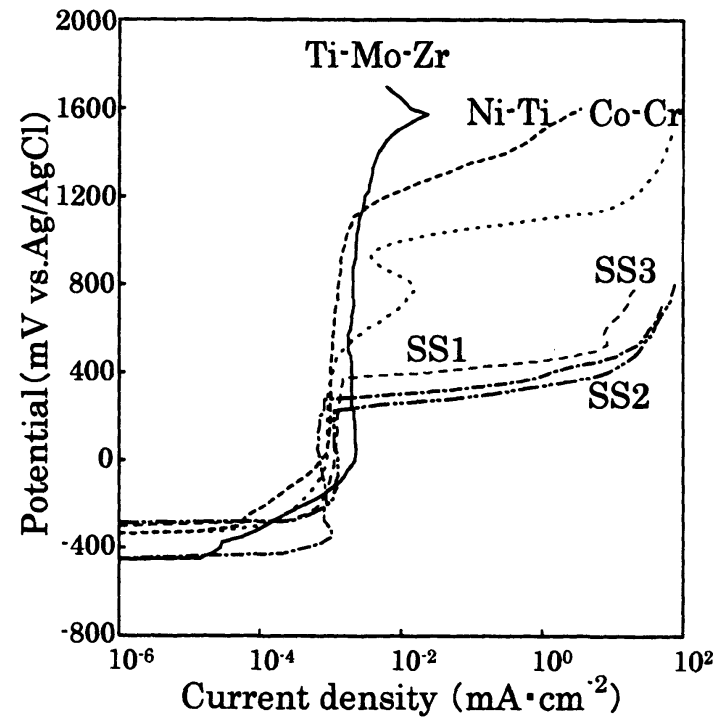

Fig. 4 Potential/current density curves of grinded wires in $0.9 \% \mathrm{NaCl}$ solution.

\section{Potentiodynamic polarization measurements}

Fig. 3 shows the potentiodynamic anodic polarization curves for the as-received wires in deaerated $0.9 \%$ $\mathrm{NaCl}$ solution. The passive current density for the three stainless wires abruptly increased at approximately $350-400 \mathrm{mV}$ due to an initiation and growth of pits. The breakdown potentials of the Ni-Ti and Co$\mathrm{Cr}$ wires were much higher than those for the stainless steel wires. The passivity of the Ti-Mo-Zr wire was stable from the free corrosion potential up to $+1800 \mathrm{mV}$. Similar results were obtained from the grinded wires as shown in Fig. 4. The passive current density, however, was larger for the grinded wire than for the as-received wire. This was evident for the two Ti alloys and the SS1 wire.

\section{DISCUSSION}

General corrosion resistance of the as-received wires For all wires tested, no localized corrosion such as pitting occurred on the surface after immersion in $0.9 \% \mathrm{NaCl}$ solution for four weeks. The total amount of metal ions released from the $\mathrm{Ti}$ alloy wires was remarkably smaller than that from the Co-Cr and stainless steel wires (Figs. 1 and 2), demonstrating that the resistance to general corrosion for the Ti alloy wires was much higher than that for the other two types of wires. A recent study demonstrated that the as-received $\mathrm{Co}-\mathrm{Cr}-\mathrm{Ni}$ alloy wire exhibits a satisfactory low corrosion rate that is nearly equal to beta-Ti alloy wire ${ }^{12)}$. The present study, however, demonstrated that the general corrosion resistance of the Co-Cr wire evaluated from the dissolution of metal ions was the lowest among the wires tested, and this wire released large amount of Co and $\mathrm{Ni}$ ions into $0.9 \% \mathrm{NaCl}$ solution. This result is consistent with the findings obtained by Rose et $a l{ }^{13)}$, in that the $\mathrm{Co}-\mathrm{Cr}-\mathrm{Ni}$ alloy orthodontic wire severely inhibited the rate of cell proliferation due to the released $\mathrm{Co}$ and $\mathrm{Ni}$ ions.

Among the three stainless steels wires, general corrosion resistance of the SS1 wire was a little higher than that of the SS2 and SS3 wires. This slight increase in the corrosion resistance for the SS1 was probably attributed to its high $\mathrm{Cr}$ content (18.3\%). Although the Cr content of the SS3 wire was as high as that of SS1 wires, a large amount of $\mathrm{Mn}$ was released from the SS3 wire due to its high Mn content (16.4\%), which lowered the general corrosion resistance.

Localized corrosion resistance of the as-received wire The potentiodynamic polarization measurements demonstrated that the susceptibility of stainless steel wires to localized corrosion was the highest among the wires tested whereas the passivity of the Ti-Mo$\mathrm{Zr}$ wire was the most stable in a chloride solution. These results are consistent with those of the previous study ${ }^{12}$. There is a controversy, however, concerning the localized corrosion resistance of $\mathrm{Ni}-\mathrm{Ti}$ wire. Speck et $a l^{14)}$ reported that the corrosion resistances of the $\mathrm{Ni}-\mathrm{Ti}$ alloy wire in Hanks' physiological solution at $37^{\circ} \mathrm{C}$ was higher than that of $316 \mathrm{~L}$ stainless steel, $\mathrm{Co}-\mathrm{Cr}-\mathrm{Mo}$, and $\mathrm{Co}-\mathrm{Ni}-\mathrm{Mo}$ wires. In contrast, Sarkar et al. ${ }^{15)}$ pointed out that Ni-Ti alloy wire was more susceptible to pitting corrosion than stainless steel, $\mathrm{Co}-\mathrm{Cr}-\mathrm{Ni}$, and $\mathrm{Ti}-\mathrm{Mo}-\mathrm{Zr}$ wires in $1 \%$ $\mathrm{NaCl}$ solution. Rondelli et al. ${ }^{16,17)}$ also suggested by potentiodynamic polarization that the $\mathrm{Ni}-\mathrm{Ti}$ alloy and stainless steel wires were potentially susceptible to pitting in $0.9 \% \mathrm{NaCl}$ solution while $\mathrm{Co}-\mathrm{Cr}-\mathrm{Ni}$ alloy wire was immune from pitting. In the present 
study, we demonstrated that the breakdown potential for the $\mathrm{Ni}-\mathrm{Ti}$ wire in $0.9 \% \mathrm{NaCl}$ solution was markedly higher than that for the stainless steel wires by approximately $700-800 \mathrm{mV}$, and slightly higher than that for $\mathrm{Co}-\mathrm{Cr}$ wire. The difference in reported breakdown potential values among the researchers might be attributed to the different surface texture of the Ni-Ti alloy wires employed in each study. Rondelli et al. ${ }^{17)}$ demonstrated that the corrosion resistance of $\mathrm{Ni}-\mathrm{Ti}$ alloy was markedly reduced with an increase in the surface roughness. Kimura et al. ${ }^{18)}$ also reported that edges of $\mathrm{Ni}-\mathrm{Ti}$ alloy specimen were preferred initiation sites for pitting. Since susceptibility to localized corrosion is greatly changed by surface textures, the resistance of the $\mathrm{Ni}-\mathrm{Ti}$ alloy wire to pitting and crevice corrosion resistance should be further evaluated in simulated clinical situations, i.e. in the presence of surface scratches made when a wire is bent or in the presence of crevices created at a site where a wire is in contact with a bracket slot.

\section{Effect of grinding on the corrosion resistance of or- thodontic wires}

The passivity of the Ti-Mo-Zr wire was so stable that there was no significant difference between the as-received and the grinded wires in the amount of released metal ions. Except for the Ti-Mo-Zr and SS2 wires, the amount of released metal ions in most of the elements was increased by grinding the wire surface before they were immersed in $0.9 \% \mathrm{NaCl}$ solution $(\mathrm{p}<0.01)$. Our previous study demonstrated that a thick oxide film mainly composed of $\mathrm{TiO}_{2}$ was formed on the commercial $\mathrm{Ni}-\mathrm{Ti}$ alloy orthodontic wire as a result of the production processes, such as the heat treatment and pickling processes, and that this oxide film caused an increase in both the general and localized corrosion resistance of the Ni-Ti orthodontic wire in $0.9 \% \mathrm{NaCl}$ solution $^{8)}$. The results shown in Figs. 1 and 2 suggest the presence of the protective oxide film on the as-received $\mathrm{Co}-\mathrm{Cr}-\mathrm{Ni}$, SS1 and SS3 wires as well as on the as-received Ni-Ti wire. Since the removal of this protective film leads to an increase in the corrosion rate for orthodontic wires, more metal ions may be released from the archwire end and the archwire surfaces which have scratches due to bending or ligating clinically.

The corrosion rate of the grinded wires decreased with time due to an aging of the surface oxide film when the wires were freely immersed in $0.9 \% \mathrm{NaCl}$ solution. The corrosion rate, however, would temporarily increase if the abrasion removes the oxide film on the wire surface in clinical use. Thus, further study is necessary to evaluate the effects of mastication and tooth brushing on the corrosion behavior of the orthodontic wires.
Potential risk of inducing hypersensitive reactions for each orthodontic wire in relation to the corrosion characteristics

It is well known that $\mathrm{Ni}$ is one of the most common causes of allergic contact dermatitis ${ }^{3,4)}$. The other base metals such as $\mathrm{Co}, \mathrm{Cr}$, and $\mathrm{Sn}$ are also allergenic, but far less than $\mathrm{Ni}^{7)}$. Kerosuo et $a l^{4)}$ investigated the frequency of $\mathrm{Ni}$ hypersensitivity in 700 Finnish adolescents in relation to orthodontic treatment and showed that orthodontic treatment did not seem to affect the prevalence of $\mathrm{Ni}$ sensitization. There are, however, several case reports ${ }^{5,6)}$ which indicate a risk of sensitizing the patient to $\mathrm{Ni}$ during the orthodontic treatment with metallic appliances. Dunlap et $a l .{ }^{5)}$ reported that a teenaged patient developed typical allergic contact stomatitis with the placement of orthodontic wire made of $\mathrm{Ni}-\mathrm{Ti}$ alloy, and that removal of this wire resulted in the complete cleansing of lesions within 4 days. Bass et $a l^{3)}$ also reported that two patients developed Ni sensitivity during orthodontic treatment. These findings suggest that there is a risk of inducing a $\mathrm{Ni}$ hypersensitivity reaction with long-term exposure to metallic appliances in routine clinical orthodontics, although the risk does not seem to be high.

An immunological threshold limit for absorbing metal ions from a metallic orthodontic appliance in contact with oral tissues and saliva has not been established. However, the less amount of released metal ions, the better in order to reduce the risk. From this stand point, the Ti-Mo-Zr wire is obviously the most suitable orthodontic wire since this wire does not contain allergenic metals such as $\mathrm{Ni}$, $\mathrm{Co}$, and $\mathrm{Cr}$, and the resistance to both general and localized corrosion is the highest among the six wires investigated.

A reduction in $\mathrm{Ni}$ content and an increase in corrosion resistance are both effective in reducing the dissolution of $\mathrm{Ni}$ ions from the wires. In the case of austenitic stainless steel, a reduction in $\mathrm{Ni}$ content and a significant increase in the localized corrosion resistance is achieved by the addition of a small amount of nitrogen ${ }^{19,20)}$. The release of $\mathrm{Ni}$ ions from the SS3 wire made of high nitrogen-bearing austenitic stainless steel with a trace amount of $\mathrm{Ni}$ was below the detection limit, suggesting that this wire may be one of the materials of choice for $\mathrm{Ni}$ sensitive patients. The composition of the SS3 wire, however, should be further examined to improve the general and localized corrosion resistance.

\section{CONCLUSION}

Under the conditions of this study, the following conclusions can be drawn.

1. Ti alloy orthodontic wires (Ni-Ti and beta-Ti) exhibited higher resistance to both general and localized corrosion than $\mathrm{Co}-\mathrm{Cr}$ wire and stainless steel 
(SS1, SS2 and SS3) wires.

2. The oxide film on the as-received $\mathrm{Ni}-\mathrm{Ti}, \mathrm{Co}-\mathrm{Cr}$, SS1 and SS2 wires contributed to the prevention of the release of metal ions.

3 . Since a small amount of $\mathrm{Ni}, \mathrm{Cr}$ or $\mathrm{Co}$ ions were released from $\mathrm{Ni}-\mathrm{Ti}, \mathrm{Co}-\mathrm{Cr}$ and stainless steel wires, special attention should be paid to their clinical use. 4. From the viewpoint of corrosion characteristics and allergenic properties, the $\mathrm{Ti}-\mathrm{Mo}-\mathrm{Zr}$ wire is the most suitable and biocompatible orthodontic wire.

\section{ACKNOWLEDGMENTS}

We wish to thank Tomy International, Rocky Mountain Orthodontics, 3M Unitek and Dentaurum for supplying the orthodontic wires.

\section{REFERENCES}

1) Brantley WA. Orthodontic wires. In: Brantley WA, Eliades T, editors. Orthodontic Materials. Scientific and Clinical aspects. Stuttgart: Thieme; 2000, p.77-103.

2) Kusy RP. A review of contemporary archwires: Their properties and characteristics. Angle Orthod 1997; $67(3)$ : 197-208.

3) Bass JK, Fine HF, Cisneros GJ. Nickel hypersensitivity in the orthodontic patient. Am $J$ Orthod Dentofacial Orthop 1993; 103: 280-285.

4) Kerosuo H, Kullaa A, Kerosuo E, Kanerva L, HenstenPettersen A. Nickel allergy in adolescents in relation to orthodontic treatment and piercing of ears. Am J Orthod Dentofacial Orthop 1996; 109: 148-154.

5) Dunlap CL, Vincent SK, Barker BF. Allergic reaction to orthodontic wire: report of case. J Am Dent Assoc 1989; 118: 449-500.

6) Greppi AL, Smith DC, Woodside DG. Nickel hypersensitivity reactions in orthodontic patients. Uni Tor Dent 1989; J 3: 11-14.

7) Hildebrand HF, Veeron C, Martin P. Nickel, chromium, cobalt dental alloys and allergic reactions: an overview. Biomaterials 1989; 10: 545-548.

8) Iijima M, Endo K, Ohno H, Yonekura Y, Mizoguchi I. Corrosion behavior and surface structure of orthodontic Ni-Ti alloy wires. Dent Mater J 2001; 20(1): 103-
113.

9) Barrett RD, Bishara SE, Quinn JK. Biodegradation of orthodontic appliances. Part I . Biodegradation of nickel and chromium in vitro. Am $\mathrm{J}$ Orthod Dentofacial Orthop 1993; 103: 8-14.

10) Kerosuo H, Moe G, Kleven E. In vitro release of nickel and chromium from different types of simulated orthodontic appliances. Angle Orthod 1995; 65(2): 111-116.

11) Jia W, Beatty MW, Reinhardt RA, Petro TM, Cohen DM, Maze CR, Strom EA, Hoffman M. Nickel release from orthodontic arch wires and cellular immune response to various nickel concentrations. J Biomed Mater Res 1999; 48: 488-495.

12) Hunt NP, Cunningham SJ, Golden CG, Sheriff M. An investigation into the effect of polishing on surface hardness and corrosion of orthodontic archwires. Angle Orthod 1999; 69(5): 433-440.

13) Rose EC, Jonas IE, Kappert HF. In vitro investigation into the biological assessment of orthodontic wires. $J$ Orofac Orthop 1998; 59(5): 253-264.

14) Speak KM, Fraker AC. Anodic polarization behavior of Ti-Ni and Ti-6Al-4V in simulated physiological solutions. J Dent Res 1980; 59(10): 1590-1595.

15) Sarkar NK, Redmond W, Schwaninger B, Goldberg AJ. The chloride corrosion behavior of four orthodontic wires. J Oral Rehab 1983; 10: 120-128.

16) Rondelli G, Vicentini B. Localized corrosion behavior in simulated human body fluids of commercial $\mathrm{Ni}-\mathrm{Ti}$ orthodontic wires. Biomaterials 1999; 20: 785-792.

17) Rondelli G, Vicentini B. Evaluation by electrochemical tests of the passive film stability of equiatomic $\mathrm{Ni}-\mathrm{Ti}$ alloy in presence of stress-induced martensite. $J$ Biomed Mater Res 1999; 51(1): 47-54.

18) Kimura K, Sohmura T. Corrosion resistance in surface coated $\mathrm{Ti}-\mathrm{Ni}$ shape memory alloy. J J Dent Mater 1987; 6(1): 73-79.

19) Endo K, Abiko Y, Suzuki M, Ohno H, Kaku T. Corrosion resistance and biocompatibility of high nitrogenbearing stainless steels. Zairyo-to-Kankyo 1998; 47: 570576.

20) Endo K, Suzuki M, Ohno H. Corrosion characteristics of ferric and austenitic stainless steels for dental magnetic attachment. Dent Mater J 2000; 19(1): 34-49. 